\title{
Some noteworthy and new records of Liverworts from Barail Wildlife Sanctuary, Assam, India
}

\author{
Sudipa Das $^{1^{*}}$ and G. D. Sharma ${ }^{2}$ \\ ${ }^{1}$ Department of Life Science \& Bioinformatics, Assam University, Silchar 788 011, Assam, India \\ ${ }^{2}$ Bilaspur University, Bilaspur, Chhattisgarh 495 009. India.
}

\section{Article history}

Received: 9 February 2016

Accepted: 30 March 2016

Published: 04 April 2016

(C) Das and Sharma (2016)

Special Section: New Frontiers in Cryptogamic Botany

Section Editor

Afroz Alam

Publisher

Horizon e-Publishing Group

Corresponding Author

Sudipa Das

$\square_{\text {sudipadb@yahoo.in }}$

\begin{abstract}
Barail Wildlife Sanctuary (BWS) is situated in Southern Assam, India between the coordinates $24^{\circ} 58^{\prime}-25^{\circ} 5^{\prime} \mathrm{N}$ and $92^{\circ} 46^{\prime}-92^{\circ} 52^{\prime} \mathrm{E}$ covering an area of about $326.24 \mathrm{sq}$. $\mathrm{km}$. During subsequent explorations in the present study on the liverworts of Barail Wildlife Sanctuary, a total of 14 species have been recorded as new for the state of Assam; 12 species have been found rare within the study area; four species have been recorded as threatened due to various natural and anthropogenic factors and eight species have been found which are endemic to India.
\end{abstract}

\section{Keywords}

Bryophytes; Endemic, Marchantiophyta; Southern Assam; Threatened

Das, S and G. D. Sharma. 2016. Some noteworthy and new records of Liverworts from Barail Wildlife Sanctuary, Assam, India. Plant Science Today 3(2): 100-108. http://dx.doi.org/10.14719/pst.2016.3.2.193

\section{Introduction}

Barail Wildlife Sanctuary (BWS) (Map 1) is situated in Southern Assam, India between the coordinates $24^{\circ} 58^{\prime}-25^{\circ} 5^{\prime} \mathrm{N}$ and $92^{\circ} 46^{\prime}-92^{\circ} 52^{\prime} \mathrm{E}$ covering an area of about 326.24 sq. km. The sanctuary enjoys tropical climate coupled with heavy showers and high percentage of humidity. These conditions have helped the sanctuary to be a good abode of bryophytes.

Recently, during the present study on the group Hepaticae of Barail Wildlife Sanctuary, 14 species distributed under 10 genera and seven families have been found new for the state of Assam. 12 species have been found rare within the study area; four species as threatened due to various natural and anthropogenic factors and eight species have been found which are endemic to India.

The present communication provides an enumeration of new records of liverworts for the state of Assam reported from BWS along with rare and threatened taxa, and taxa endemic to India found within the expand of sanctuary.

\section{Materials and Methods}

This observation is based on a survey, collection and observation of liverwort taxa from different eco-regions of the study area during the years 2011 - 2014. Collection and preservation of specimens and recording of field data have been done following standard methods. Photographs of the plants had been taken in the field in their natural habitat. Identification of the specimens has been done through critical morpho-taxonomic analysis under Olympus stereo zoom dissecting microscope and labomade compound microscope. Help from standard relevant literature like protologues, monographs and floras (Sharma and Srivastava, 1993, Zhu and So, 2001, Srivastava and Srivastava, 
2002, Rawat and Srivastava, 2007, etc.) have also been taken during the identification process and also for global distribution of the taxa. Distributions are also checked from the website discoverlife.org. Threat statuses of the taxa are assessed upon personal observations of the authors. The whole work has been done following conventional methods of taxonomic study.

\section{Results and Discussion}

\section{Enumeration of Taxa}

\section{Bazzania sikkimensis (Steph.) Herzog} (Lepidoziaceae) (Fig.1 A).

Habitat: Terrestrial. Growing in moist rock crevices under shady and extremely waterlogged condition.

Specimen examined: India, Assam, Cachar district, Barail Wildlife Sanctuary, Indranagar, ca 70 m, S. Das 25075, Assam University Herbarium.

Distribution: It is distributed in Arunachal Pradesh, Assam (present study), Meghalaya, Sikkim and West Bengal in India and also in Nepal, Bhutan, China, Taiwan, Philippines and Thailand (Sharma and Srivastava, 1993; Zhu, 2006; Lai et al., 2008; Singh, Singh and Dey, 2008; Das, 2009; Pradhan and Joshi, 2009; Wang et al., 2011).

Current status: New record for the state of Assam. Rare.

\section{Cephalozia pandei Udar \& D. Kumar (Cephaloziaceae).}

Habitat: Terrestrial. Growing on a thin film of loose sandy soil over rock in moist \& shady places.

Specimen examined: India, Assam, Cachar district, Barail Wildlife Sanctuary, Malidar, ca 70 m, S. Das 25036a, Assam University Herbarium.

Distribution: It is distributed in Arunachal Pradesh, Assam, Meghalaya and West Bengal in India (Udar and Kumar, 1976; Singh, Nath and Asthana, 2003; Das, 2009; Das and Sharma, 2013).

Current status: Endemic.

\section{Jungermannia gollanii Steph. (Jungermanniaceae).}

Habitat: Terrestrial. Growing on loose soil over rock and limestone rock along the river.

Specimen examined: India, Assam, Cachar district, Barail Wildlife Sanctuary, Indranagar, ca 70 m, S. Das 25076, 25086, Assam University Herbarium.

Distribution: It is distributed in Assam (present study), Sikkim and Uttarakhand in India and also in Nepal, Bhutan and China (Pradhan and Joshi, 2009; Vaňa and Long, 2009).
Current status: New record for the state of Assam.

4. Solenostoma clavellatum Mitt. ex Steph. (Jungermanniaceae).

Habitat: Terrestrial. Growing on bare moist rock or on a thin film of sandy soil over rock, near a ditch.

Specimen examined: India, Assam, Cachar district, Barail Wildlife Sanctuary, Marwachhera, ca 50 m, S. Das 25055, 25059, Assam University Herbarium.

Distribution: It is distributed in Assam (present study), Meghalaya and Sikkim in India and also in Nepal, Bhutan and China (Zhu, 2006 as 'Jungermannia clavellata (Mitt. ex Steph.) Amakawa'; Singh et al, 2008 as 'J. clavellata'; Pradhan and Joshi, 2009 as 'J. clavellata'; Vaňa and Long, 2009).

Current status: New record for the state of Assam.

5. Solenostoma sikkimensis (Schiffn. ex Steph.) Vaňa et D.G.Long (Jungermanniaceae).

Habitat: Terrestrial. Growing on thin film of sandy soil over rock, near a ditch.

Specimen examined: India, Assam, Cachar district, Barail Wildlife Sanctuary, Marwachhera, ca $50 \mathrm{~m}, \quad$. Das 25055a, Assam University Herbarium.

Distribution: It is distributed in Assam (present study), Meghalaya and West Bengal in India and also in Bhutan and China (Vaňa and Long, 2009).

Current status: New record for the state of Assam.

\section{Chiloscyphus campanulatus Steph. (Geocalycaceae).}

Habitat: Terrestrial. Growing on moist soil in shady places or on a thin film of soil over a rock wall exposed to sunlight, along the roadside.

Specimen examined: India, Assam, Cachar district, Barail Wildlife Sanctuary, $25 \mathrm{~km}$ away from Kumbirgram, ca 70; Marwachhera, ca $50 \mathrm{~m}$, S. Das 25008; S. Das 25051a, Assam University Herbarium.

Distribution: It is distributed in Assam, Jammu \& Kashmir, Himachal Pradesh and Uttarakhand in India (Srivastava and Srivastava, 2002; Singh and Singh, 2009; Das Bhattacharyya, Bhattacharyya and Sharma, 2011; Das and Sharma, 2013).

Current status: Endemic.

7. Heteroscyphys bescherellei (Steph.) S. Hatt. (Geocalycaceae). 


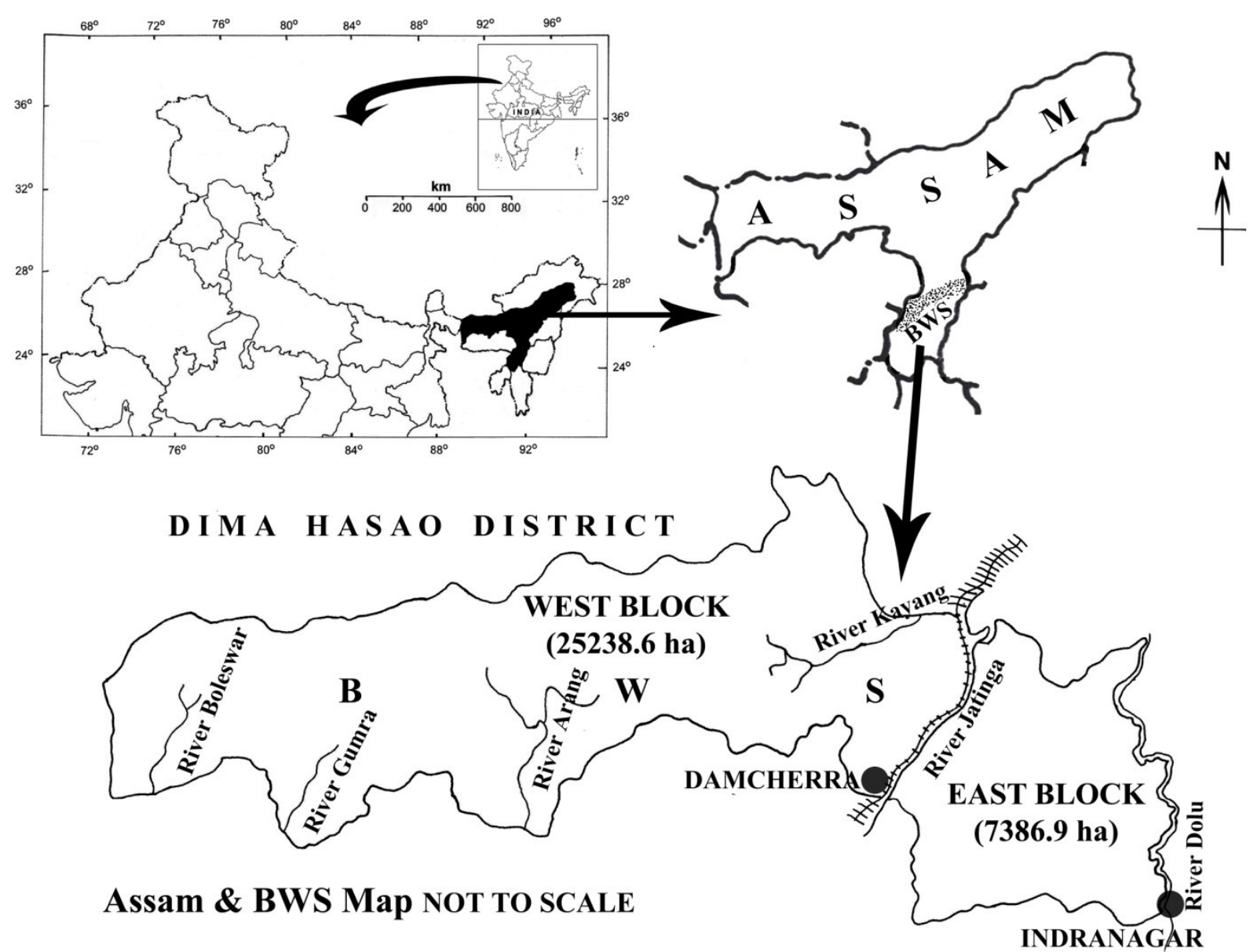

Map 1: Barail Wildlife Sanctuary (BWS), Assam. (Map Source: Das \& Sharma, 2013)

Habitat: Terrestrial. Growing in moist and shady place under rock crevices.

Specimen examined: India, Assam, Cachar district, Barail Wildlife Sanctuary, Indranagar, ca 80 m, S. Das 25174, Assam University Herbarium.

Distribution: It is distributed in Arunachal Pradesh, Assam (present study), Manipur, Meghalaya, Sikkim and West Bengal in India and also in Nepal, China, Japan, Philippines, New Guinea and Australia (Srivastava and Srivastava, 2002; Singh et al., 2008; Das, 2009; Singh et al., 2010).

Current status: New record for the state of Assam.

8. Heteroscyphus orbiculatus Abha Srivast. \& S.C. Srivast., (Geocalycaceae).

Habitat: Terrestrial. Growing on loose soil over rock.

Specimen examined: India, Assam, Cachar district, Barail Wildlife Sanctuary, Malidar, ca 70 m, S. Das 25041, Assam University Herbarium.

Distribution: It is distributed in Arunachal Pradesh, Assam, Himachal Pradesh and Tamil Nadu in India (Srivastava and Srivastava, 2002;
Singh and Singh, 2003; Das, 2009; Das and Sharma, 2013).

Current status: Endemic and Rare.

9. Heteroscyphus palniensis Abha Srivast. \& S.C. Srivast. (Geocalycaceae).

Habitat: Terrestrial. Growing on bare moist rock beneath River bed; occasionally submerged during monsoon.

Specimen examined: India, Assam, Cachar district, Barail Wildlife Sanctuary, Malidar, ca 80 m, S. Das 25030, Assam University Herbarium.

Distribution: It is distributed in Assam, Sikkim and Tamil Nadu in India (Srivastava and Srivastava, 2002, Dey, Singh and Singh, 2009; Singh and Barbhuiya, 2012; Das and Sharma, 2013).

Current status: Endemic.

10. Heteroscyphus pandei S.C. Srivast. \& Abha Srivast. (Geocalycaceae).

Habitat: Terrestrial. Growing on damp soil in shady places in association with mosses. 
Specimen examined: India, Assam, Cachar district, Barail Wildlife Sanctuary, Marwachhera, ca $50 \mathrm{~m}$, S. Das 25023, Assam University Herbarium.

Distribution: It is distributed in Assam, Manipur, Sikkim, West Bengal, Himachal Pradesh and Uttarakhand in India and also in Nepal (Srivastava and Srivastava, 2002; Singh et al., 2008; Singh and Singh, 2009; Singh, Dey and Singh, 2010; Das and Sharma, 2012, 2013).

Current status: Rare and Threatened.

11. Heteroscyphus parvus Abha Srivast. \& S. C. Srivast. (Geocalycaceae).

Habitat: Terrestrial. Growing on damp, the extremely moist soil along the ditch.

Specimen examined: India, Assam, Cachar district, Barail Wildlife Sanctuary, Kaong, ca 70 m, S. Das 25121, Assam University Herbarium.

Distribution: It is distributed in Arunachal Pradesh, Assam (present study), Madhya Pradesh and Sikkim in India and also in Nepal (Srivastava and Srivastava, 2002; Singh et al., 2008; Das, 2009).

Current status: New record for the state of Assam.

12. Plagiochila defolians Grolle \& M.L.So (Plagiochilaceae) (Fig.1 B).

Habitat: Epiphytic. Growing on branches of Fig tree and rough stem bark of other angiosperms in dense forest.

Specimen examined: India, Assam, Cachar district, Barail Wildlife Sanctuary, Lakhichhera, ca 90 m, S. Das 25218, 25222a, 25272 , Assam University Herbarium.

Distribution: It is distributed in Assam (present study) and West Bengal in India and also in China (So, 2001; Zhu, 2006; Rawat and Srivastava, 2007).

Current status: New record for the state of Assam.

\section{Plagiochila grollei Inoue (Plagiochilaceae).}

Habitat: Terrestrial. Growing in crevices of rocks under shady condition.

Specimen examined: India, Assam, Cachar district, Barail Wildlife Sanctuary, Marwachhera, ca $50 \mathrm{~m}$, S. Das 25071, Assam University Herbarium.

Distribution: It is distributed in Assam and West Bengal in India and also in Bhutan, Nepal, China and Vietnam (So, 2001; Rawat and Srivastava, 2007; Das and Sharma, 2013).
14. Archilejeunea apiculifolia Steph. (Lejeuneaceae) (Fig.1 C).

Habitat: Epiphytic. Growing on the stem bark of the fig tree in the vicinity of the forest, under exposed condition.

Specimen examined: India, Assam, Cachar district, Barail Wildlife Sanctuary, Indranagar, ca 80 m, S. Das 25080, Assam University Herbarium.

Distribution: It is distributed in Assam (present study), Kerala, Tamil Nadu (Udar and Awasthi 1981, 1981a; Nair, Rajesh and Madhusoodanan, 2008).

Current status: New record for the state of Assam. Endemic and Rare.

15. Archilejeunea minutilobula Udar \& U.S. Awasthi (Lejeuneaceae).

Habitat: Epiphytic. Growing on the bark of angiosperms.

Specimen examined: India, Assam, Cachar district, Barail Wildlife Sanctuary, $25 \mathrm{~km}$ away from Kumbirgram, ca 70 m, S. Das 25010a, Assam University Herbarium.

Distribution: It is distributed in Arunachal Pradesh, Assam, Maharashtra and Tamil Nadu in India (Udar and Awasthi, 1981; Das and Singh, 2007; Singh and Barbhuiya, 2012; Das and Sharma, 2013).

Current status: Endemic.

16. Caudalejeunea reniloba (Gottsche) Steph. (Lejeuneceae).

Habitat: Epiphytic. Growing on the stem bark of the angiospermic plant in dense forest.

Specimen examined: India, Assam, Cachar district, Barail Wildlife Sanctuary, Indranagar, ca 80 m, S. Das 25079, Assam University Herbarium.

Distribution: It is distributed in Assam, Karnataka, Kerala and Andaman \& Nicobar Islands in India and also in China, Taiwan; Java, Malaysia, Africa (Kitagawa, 1971; Udar, Awasthi and Shaheen, 1982 as C. pluriplicata; Joshi, Wani and Chavan, 1989; Luo, 1990; Nair et al., 2008; Wigginton, 2009 as Caudalejeunea recurvistipula; Soderstrom, Gradstein and Hagborg, 2010 as Caudalejeunea recurvistipula; Wang et al., 2011; Sing and Barbhuiya, 2012).

Current status: Threatened.

17. Cheilolejeunea giraldiana (C. Massal) Mizut. (Lejeuneaceae).

Current status: Rare. 


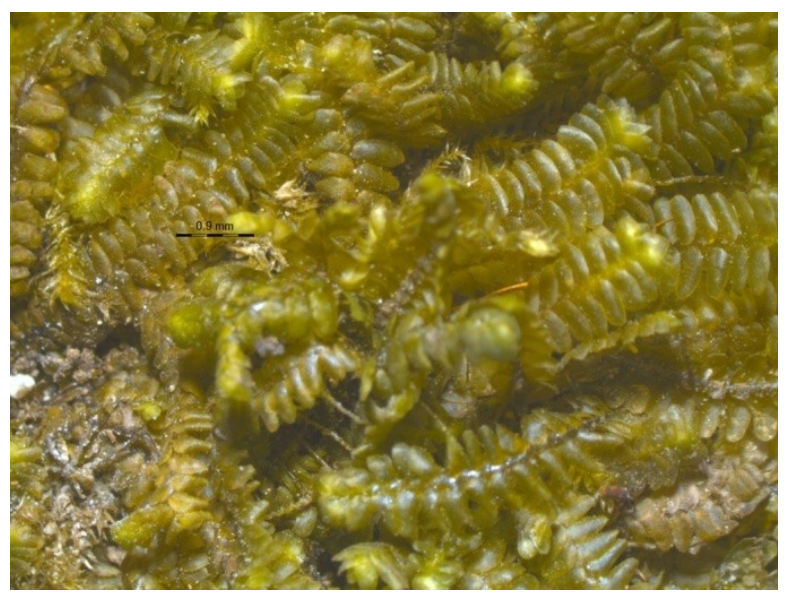

A

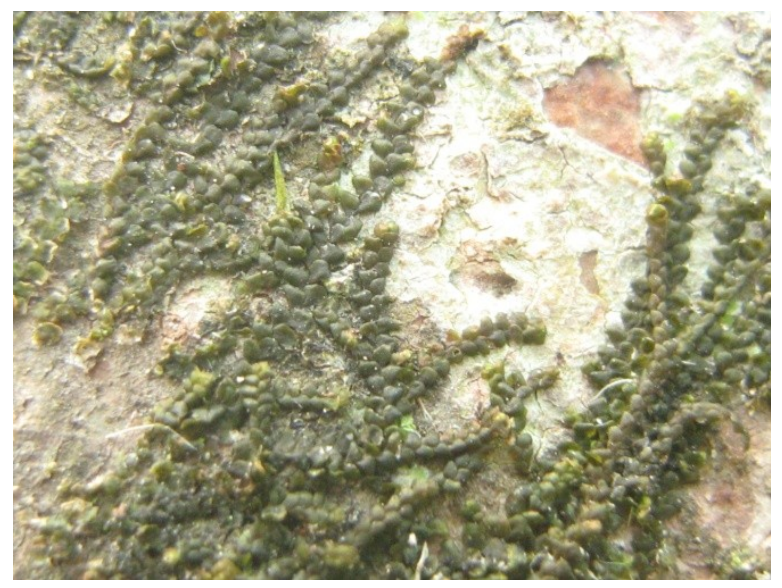

C

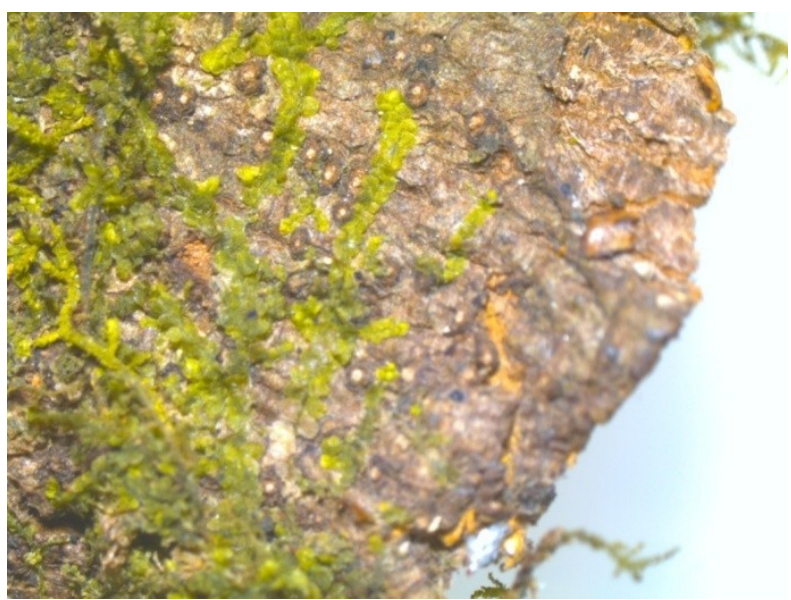

E

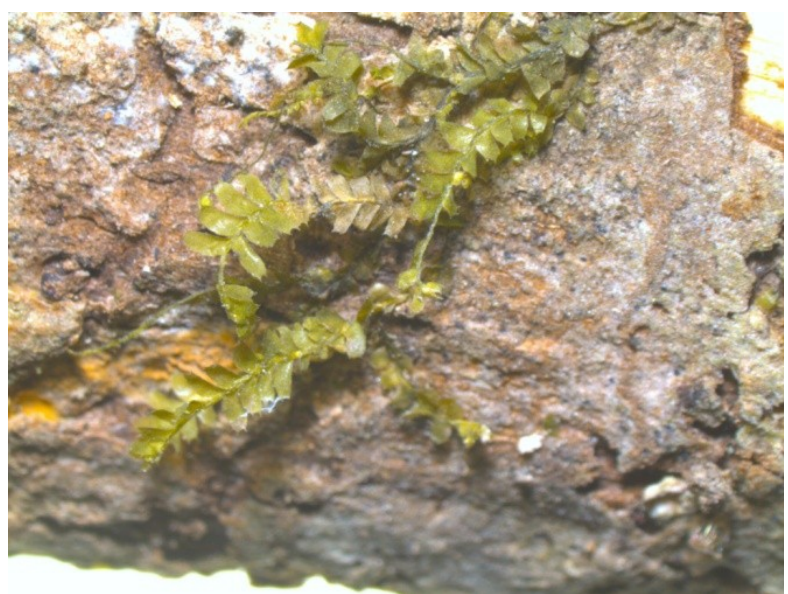

B

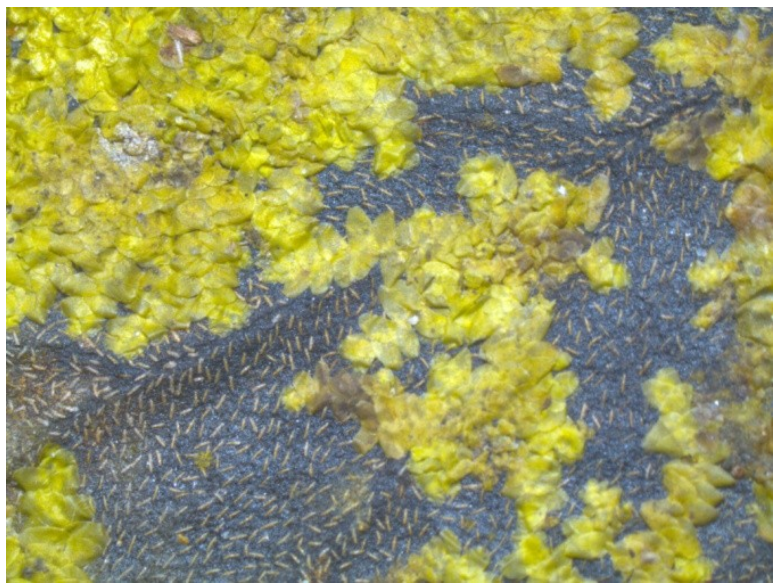

D

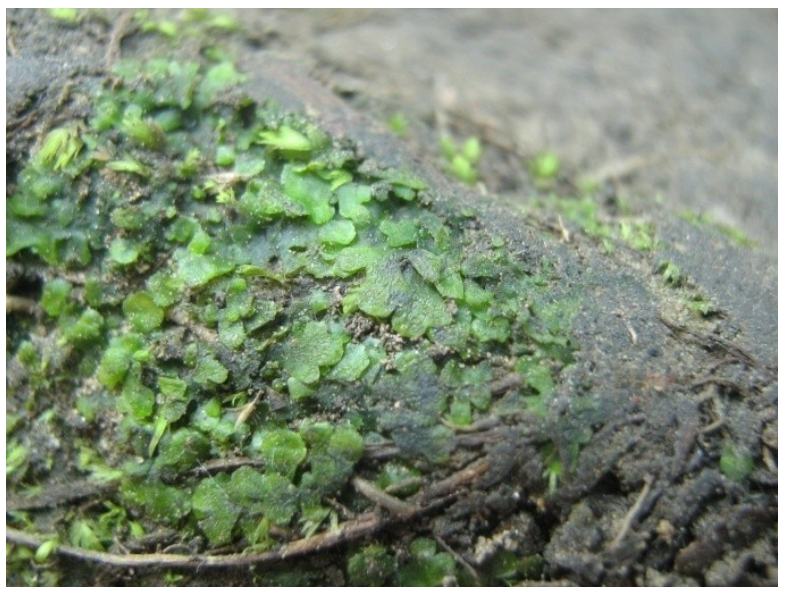

F

Fig. 1. A. Bazzania sikkimensis; B. Plagiochila defolians; C. Archilejeunea apiculifolia; D. Cololejeunea siangensis; E. Lejeunea alata; F. Riccardia levieri.

Habitat: Terrestrial. Growing on loose soil over rock in moist \& shady places.

Specimen examined: India, Assam, Cachar district, Barail Wildlife Sanctuary, $25 \mathrm{~km}$ away from Kumbirgram, ca 70 m, S. Das 25009b, Assam University Herbarium.
Distribution: It is distributed in Assam (present study), Manipur, Meghalaya, Sikkim and West Bengal in India and also in Nepal, China, Japan and Phillipines (Mizutani, 1972; Asthana et al., 1995; Singh and Nath, 2007; Singh et al., 2010). 
Current status: New record for the state of Assam. Rare.

18. Cheilolejeunea intertexta (Lindenb.) Steph. (Lejeuneaceae).

Habitat: Terrestrial. Growing on loose, moist soil in rock crevices under shady condition.

Specimen examined: India, Assam, Cachar district, Barail Wildlife Sanctuary, Malidar, ca 70 m, S. Das 25039b, Assam University Herbarium.

Distribution: It is distributed in Assam (present study), Meghalaya, Kerala, Tamil Nadu and Andaman \& Nicobar Islands in India and also in Sri Lanka, China, Hong Kong, Singapore, Indonesia, Malaysia, Japan, Taiwan, Micronesia, Nigeria and Philippines (Mizutani, 1972, 1982; Asthana et al., 1995; So and Zhu, 1996; Piippo et al., 2002; Zhu, 2006; Singh and Nath, 2007; Nair et al., 2008; Daniels, 2010; Chuah-Petiot, 2011; Wang et al., 2011).

Current status: New record for the state of Assam. Rare.

\section{Cololejeunea latilobula (Herzog) Tixier (Lejeuneaceae).}

Habitat: Epiphytic. Growing on the bark of angiosperms.

Specimen examined: India, Assam, Cachar district, Barail Wildlife Sanctuary, $25 \mathrm{~km}$ away from Kumbirgram, ca 70 m, S. Das 25010b, Assam University Herbarium.

Distribution: It is distributed in Arunachal Pradesh, Assam, Manipur, Meghalaya, Sikkim, Uttarakhand, Madhya Pradesh, Karnataka, Kerala and Tamil Nadu in India and also in China, Taiwan, Myanmar, Fiji, Africa (Asthana and Srivastava, 2003; Zhu, 2006; Nair et al., 2008; Singh et al., 2008; Das, 2009; Wigginton, 2009; Daniels, 2010; Singh et al., 2010; Pócs et al., 2011; Wang et al., 2011; Nair et al., 2012; Singh and Barbhuiya, 2012;).

Current status: Rare.

20. Cololejeunea siangensis G. Asthana \& S.C. Srivast. (Lejeuneaceae) (Fig.1 D).

Habitat: Epiphytic. Appressed to the rough stem bark of angiosperms.

Specimen examined: India, Assam, Cachar district, Barail Wildlife Sanctuary, $25 \mathrm{~km}$ away from Kumbirgram, ca 70 m, S. Das 25001, Assam University Herbarium.

Distribution: It is distributed in Arunachal Pradesh and Assam in India (Asthana and Srivastava, 2003; Das and Sharma, 2012, 2013).
Current status: Endemic and Rare.

21. Lejeunea alata Gottsche (Lejeuenaceae) (Fig.1 E).

Habitat: Epiphytic. Growing on bark in dense forest.

Specimen examined: India, Assam, Cachar district, Barail Wildlife Sanctuary, Lakhichhera, ca 90 m, S. Das 25196, Assam University Herbarium.

Distribution: It is distributed in Arunachal Pradesh, Assam (present study), Manipur, Sikkim and West Bengal in India and also in China, Indonesia, Malaysia, Papua New Guinea, Vietnam and Africa (Zhu and So, 2001; Dey and Singh, 2008; Das, 2009; Dey et al., 2009; Wigginton, 2009; Singh et al., 2010; Chuah-Petiot, 2011).

Current status: New record for the state of Assam.

22. Trocholejeunea infuscata (Mitt.) Verd. (Lejeuneaceae).

Habitat: Epiphytic, on bark of higher plants under moist condition.

Specimen examined: India, Assam, Cachar district, Barail Wildlife Sanctuary, Marwacherra ca 50 m, S. Das 25067, Assam University Herbarium.

Distribution: It is distributed in Arunachal Pradesh, Assam, Manipur, Meghalaya, Sikkim, West Bengal, Himachal Pradesh in India and also in Sri Lanka, Nepal, Bhutan, China, Myanmar, Philippines, Thailand (Mitten, 1861; Awasthi and Srivastava, 1988; Singh and Singh, 2007; Singh et al., 2008; Das, 2009; Singh et al., 2010; Singh and Barbhuiya, 2012; Das and Sharma, 2013).

Current status: Rare.

23. Riccardia levieri Schiffn. (Aneuraceae) (Fig.1 F).

Habitat: Epiphytic on twig and lignicolous on rotten wood. Growing along small water fall.

Specimen examined: India, Assam, Cachar district, Barail Wildlife Sanctuary, Ditekchhera, ca 90 m, S. Das 25123, 25124, Assam University Herbarium.

Distribution: It is distributed in Arunachal Pradesh, Assam (present study), Himachal Pradesh, Karnataka, Madhya Pradesh, Manipur, Tamil Nadu, Uttarakhand and West Bengal in India and also in Bhutan (Srivastava and Udar, 1976; Das, 2009; Singh and Singh, 2009; Singh et al., 2010).

Current status: New record for the state of Assam. 
24. Riccardia sikkimensis(Steph.) Pande \& K.P. Srivast. (Aneuraceae).

Habitat: Terrestrial. Growing in the groove of boulders along small water fall.

Specimen examined: India, Assam, Cachar district, Barail Wildlife Sanctuary, Ditekchhera, ca 90 m, S. Das 25126, Assam University Herbarium.

Distribution: It is distributed in Arunachal Pradesh, Assam (present study), Manipur, Meghalaya, Sikkim, West Bengal and Western Himalayas in India (Srivastava and Udar, 1976; Singh, 1996; Singh et al., 2010).

Current status: New record for the state of Assam. Endemic.

25. Riccardia tenuicostata Schiffn. (Aneuraceae).

Habitat: Terrestrial, on bare shady rock along roadside.

Specimen examined: India, Assam, Cachar district, Barail Wildlife Sanctuary, Malidar, ca 80 m, S. Das 25047, Assam University Herbarium.

Distribution: It is distributed in Arunachal Pradesh, Assam, Manipur, Meghalaya, Sikkim, West Bengal, Himachal Pradesh, Uttarakhand and Tamil Nadu in India and also in Singapore, Indonesia, Malaysia (Srivastava and Udar, 1976; Singh and Nath, 2007; Das, 2009; Singh and Singh, 2010; Singh et al., 2010; Söderström et al., 2010; Das and Sharma, 2013).

Current status: Rare.

26. Conocephalum japonicum (Thunb.) Grolle (Conocephalaceae).

Habitat: Terrestrial. Growing on bare moist rock beneath the riverbed.

Specimen examined: India, Assam, Cachar district, Barail Wildlife Sanctuary, Malidar, ca 70 m, S. Das 25033c, Assam University Herbarium.

Distribution: It is distributed in Arunachal Pradesh, Assam, Sikkim and West Bengal in India and also in Nepal, Bhutan, Taiwan, Korea, Japan and China (Singh, 1996; Singh and Singh, 2003a; Zhu, 2006; Das, 2009; Pradhan and Joshi, 2009; Wang et al., 2011; Das and Sharma, 2013).

Current status: Rare.

27. Marchantia geminata Reinw. et al. (Marchantiaceae).

Habitat: Terrestrial. Growing on loose sandy soil over rock.

Specimen examined: India, Assam, Cachar district, Barail Wildlife Sanctuary, Indranagar, ca 80 m, S. Das 25082, Assam University Herbarium.
Distribution: It is distributed in Andaman \& Nicobar Islands, Assam (present study) and Meghalaya in India and also in Indonesia, Malaysia and Philippines (Tan and Engel, 1986; Bischler-Causse, 1989; Singh and Nath, 2007; Söderström et al., 2010; Chuah-Petiot, 2011).

Current status: New record for the state of Assam. Threatened.

28. Marchantia papillata Raddi subsp. grossibarba (Steph.) Bischl. (Marchantiaceae).

Habitat: Terrestrial. Growing on moist soil of the riverbed, in the crevice of a boulder and also on loose sandy soil over rock.

Specimen examined: India, Assam, Cachar district, Barail Wildlife Sanctuary, Indranagar, ca 80 m, S. Das 25083, 25088, Assam University Herbarium.

Distribution: It is distributed in Arunachal Pradesh, Assam, Meghalaya, Nagaland, Sikkim, West Bengal, Jammu \& Kashmir, Himacha Pradesh, Uttarakhand, Odisha, Madhya Pradesh, Uttar Pradesh, Punjab, Rajasthan, Kerala and Tamil Nadu in India and also in Sri Lanka, Bangladesh, Nepal, Bhutan, Pakistan, Afganistan, China, Myanmar and Thailand (Kashyap, 1929; Pande and Srivastava, 1952; Udar and Jain, 1984; BischlerCausse, 1989; Barukial, Gogoi and Barua, 2002 as M. palmata; Singh and Nath, 2007; Lai et al., 2008; Singh et al., 2008; Pradhan and Joshi, 2009; Daniels, 2010; Singh and Singh, 2010; Singh and Barbhuiya, 2012; Alam et al., 2013 as M. palmata).

Current status: Threatened.

\section{Conclusion}

During our survey, we have identified several detrimental effects on the liverworts growing in BWS due to various anthropogenic activities, mainly on those, growing in the buffer and transition zones of the sanctuary. Each rare taxon has been found restricted in a single small locality. Whereas, in case of the threatened taxa, some of them were reported from more than one locally within the study area during initial visits. But in subsequent explorations to those localities, they couldn't be relocated in some of their early locations. Cutting of roadside rock walls and the destruction of forests due to construction of highways through the forest is the main cause of threat for the plants. Apart from that, cutting of trees and logs for unauthorized wood trade by the local people and villagers living in the vicinity of forest is also destroying the microhabitat of tiny epiphytic taxa. Attempts for in situ and ex situ conservation of the rare and threatened taxa have been done in the field and in the laboratory, respectively to check further decline in the liverwort diversity of BWS. 


\section{Authors' Contribution}

SD carried out the whole research, including field exploration, plant collection, identification, assessment and manuscript preparation. GDS is the mentor of SD. Both SD and GDS have gone through the final manuscript, read and approved it.

\section{Acknowledgements}

The authors are grateful to the Head, Department of Life Science and Bioinformatics, Assam University, Silchar for facilities. They also thank the Officer in-charge, Forest Department, Cachar \& Karimganj Division of Barail Wildlife Sanctuary, Assam for permitting exploration work within the sanctuary. One of the authors (SD) is thankful to University Grants Commission, New Delhi, India for financial assistance under the UGC-Dr. D. S. Kothari Postdoctoral Fellowship Scheme.

\section{References}

http://www.discoverlife.org - accessed on 16.07.2015.

Alam, A., K.K. Behera, S. Vats. and , I. Mudassar. 2013. A preliminary study on bryodiversity of Similipal Biosphere Reserve (Odisha), India. Arch Bryol 157: 1-9.

Asthana, G., S.C. Srivastava, and A.K. Asthana. 1995. The genus Cheilolejeunea in India. Lindbergia 20: 125143.

Asthana, G. and S.C. Srivastava. 2003. Indian Cololejeunea. A taxonomic study. Bryophyt Biblioth 60.

Awasthi, U. S. and S.C. Srivastava. 1988. Status of Brachiolejeunea (Spruce) Schiffn. in India. Proc Indian Acad Sc (Pl. Sc.) 98: 1-12.

Barukial, J., P. Gogoi, and P.K. Barua. 2002. A Checklist of Bryophytes of Brahmaputra Valley, Assam, India. Adv Pl Sc 15: 89-94.

Bischler-Causse, H. 1989. Marchantia L. The Asiatic and Oceanic taxa. Bryophyt Biblioth 38:1-317

Chuah-Petiot, M.S. 2011. A Checklist of Hepaticae and Anthocerotae of Malaysia. Pol Bot J. 56:1-44

Daniels, A.E.D. 2010. Checklist of the Bryophytes of Tamil Nadu, India. Arch Bryol 65: 1-117.

Das, S. 2009. Morpho-Taxonomic Studies on the Hepaticae and Anthocerotae of Mehao Wildlife Sanctuary, Arunachal Pradesh. University of Calcutta, Kolkata, India. Ph.D. Thesis. (Unpublished).

Das, S. and G.D. Sharma. 2012. Three new records of Marchantiophyta for the state of Assam from Barail Wildlife Sanctuary. Assam Univ J Sc Tech (Biological and Environmental Science) 10(1): 13-15.

Das, S. and G.D. Sharma. 2013. Inventorization of Marchantiophyta in Barail Wildlife Sanctuary, Assam, India with special reference to their Microhabitat. Arch Bryol 166: 1- 27.

Das, S. and D.K. Singh. 2007. Two interesting records of Liverworts from Mehao Wildlife Sanctuary, Arunachal Pradesh, India. Bull Bot Surv India 49 (14): $211-214$

Das Bhattacharyya, S., D. Bhattacharyya, and G.D. Sharma. 2011. Disjunct distributional record of an endemic liverwort Chiloscyphus Campanulatus Steph. from Assam in Indo-Burma Biodiversity Hotspot. Curr Sci 101 (7): 825- 827.

Dey, M., D. Singh, and D.K. Singh. 2009. Some new and noteworthy records of Hepaticae from Eastern Himalaya, India. Indian J Forest 32: 669- 684.

Dey, M. and D.K. Singh. 2008. Lejeunea alata Gottsche (Lejeuneaceae) - a new record for Indian bryoflora from Arunachal Pradesh. Geophytology 37: 43-45.

Joshi, D.Y., D.D. Wani, and S.J. Chavan. 1989. Studies on the Hepatic flora of the Andaman Islands (India) - I. Adv Pl Sc 2: 169-177.

Kashyap S. R. 1929. Liverworts of the Western Himalayas and the Panjab Plain I. The University of the Panjab, Lahore.

Kitagawa, N. 1971. A small collection of Hepaticae from Penang, Malaysia-continued. Bull Nara Univ Educ 20 (2): 7- 4.

Lai, M.J., R.L. Zhu, and S. Chantanaorrapint. 2008. Liverworts and Hornworts of Thailand: An updated checklist and bryofloristic accounts. Ann Bot Fennici 45: 321-341. doi: 10.5735/085.045.0501

Luo, J.S. 1990. A Synopsis of Chinese Epiphyllous Liverworts. Trop Bryol 2: 161-166.

Mitten, W. 1861. Hepaticae Indiae Orientalie, an Enumeration of the Hepaticae of the East Indies. $J$ Proc Linn Soc Botany 5: 89-128. doi: 10.1111/j.10958312.1860.tb01045.x

Mizutani, M. 1972. Studies of little known Asiatic species of Hepaticae in the Stephani Herbarium 7. Some little known species of the subfamily Lejeuneoidead of the Lejeuneaceae. J Hattori Bot Lab 35: 399-411.

Mizutani, M. 1982. Notes on the Lejeuneaceae. 6. Japanese species of the genus Cheilolejeunea. $J$ Hattori Bot Lab 51: 151-173.

Nair, M.C., T. Pócs, K.P. Rajesh, and R. Prakashkumar. 2012. Lejeuneaceae (Marchantiophyta) of the Western Ghats, India. Acta Biol Pl Agriensis 2: 125145.

Nair, M.C., K.P. Rajesh, and P.V. Madhusoodanan. 2008. Checklist of the bryophytes of Kerala, India. Trop Bryol Res Rep 7: 1-24

Pande, S.K. and K.P. Srivastava. 1952. The Hepatic vegetation of Pachmarhi (Madhya Pradesh): A preliminary survey. J Indian Bot Soc 31:342-351

Piippo, S., X.L. He, A. Juslén, B.C. Tan, D.H. Murphy, and T. Pócs. 2002. Hepatic and Hornwort flora of Singapore. Ann Bot Fennici 39: 101-127.

Pócs, T., A. Sass-Gyarmati, A. Naikatin, M. Tuiwawa, J. Braggins, S. Pócs, and M.V. Konrat. 2011. New Liverwort (Marchantiophyta) records for the Fiji Islands. Telopea 13 (3): 455-494. doi: 10.7751/telopea20116031

Pradhan, N and S.D. Joshi. 2009. Liverworts and Hornworts of Nepal: A Synopsis. Botanica Orientalis - J Pl Sc 6: 69-75.

Rawat, K.K. and S.C. Srivastava. 2007. Genus Plagiochila in Eastern Himalaya (India). Bishen Singh Mahendra Pal Singh. Dehradun.

Sharma, D. and S.C. Srivastava. 1993. Indian Lepidoziineae (A Taxonomic Revision). Bryophyt Biblioth 47: 1-353.

Singh, A.P. and V. Nath. 2007. Hepaticae of Khasi and Jaintia Hills: Eastern Himalayas. Bishen Singh Mahendra Pal Singh, Dehradun. 
Singh, A. P., V. Nath, and A.K. Asthana. 2003. Studies on Cephalozia Pandei Udar et Kumar from Meghalaya: India. Cryptogamie Bryologie 24 (4): 335-340.

Singh, D., M. Dey, and D.K. Singh. 2010. A Synoptic flora of liverworts and hornworts of Manipur. Nelumbo 52: 9-52.

Singh, D.K. 1996. Hepaticae (Bryophyta). In P. K. Hajra (ed.) A Contribution to the Flora of Namdapha, Arunachal Pradesh. Botanical Survey of India, Calcutta, India.

Singh, D.K., D. Singh, and M. Dey. 2008. A catalogue of the Hepaticae and Anthocerotae of Sikkim. In $\mathrm{H}$. Mohamed, B. B. Baki, A. Nasrulhaq-Boyce And P. K. Y. Lee (Eds), Bryology in the new millennium. University of Malaya, Kuala Lumpur, Malaysia: 93135.

Singh, S. K. and H.A. Barbhuiya. 2012. A compendium to marchantiophyta and anthocerotophyta of Assam, India. Arch Bryol 149: 1-30.

Singh, S.K. and D.K. Singh. 2003. Heteroscyphus Orbiculatus Srivast. et Srivast.: New to Himalayan Bryoflora. Indian J Forest 26: 317-319.

Singh, S.K. and D.K. Singh. 2003a. Conocephalum Japonicum (Thunb.) Grolle (Bryophyta: Conocephalaceae) - A liverwort rediscovered in Indian bryoflora. Indian J Forest 26: 442-444.

Singh, S.K. and D.K. Singh. 2009. Hepaticae and anthocerotae of Great Himalayan National Park and its environs (H.P.), India. Botanical Survey of India, Calcutta, India.

Singh, S.K. and D.K. Singh. 2010. A catalogue of the liverworts and hornworts of Himachal Pradesh, India. Arch Bryol 61: 1-13.

So, M.L. 2001. Plagiochila (Hepaticae, Plagiochilaceae) in China. Syst Bot Monographs 60: 1-214. doi: $10.2307 / 25027887$

So, M.L. and R.L. Zhu. 1996. Studies on Hong Kong Hepatics II. Notes on some newly recorded liverworts from Hong Kong. Trop Bryol 12: 11-20.

Söderström, L., S.R. Gradstein, and A. Hagborg. 2010. Checklist of the hornworts and liverworts of Java. Phytotaxa 9: 53-149. doi: 10.11646/phytotaxa.9.1.7
Srivastava, A. and S.C. Srivastava. 2002. Indian Geocalycaceae (Hepaticeae): A taxonomic study. Bishen Singh Mahendra Pal Singh. Dehradun.

Srivastava, S.C. and R. Udar. 1976. Indian Aneuraceae, A monographic study. Biol Mem 1: 121-154.

Tan, B.C. and J.J. Engel. 1986. An annotated checklist of Philippine Hepaticae. J Hattori Bot Lab 60: 283-355.

Udar, R. and U.S. Awasthi. 1981. The genus Archilejeunea (Spruce) Schiffn. in India. Geophytology 11(1): 72-79.

Udar, R. and U.S. Awasthi. 1981a. Observations on Archilejeunea apiculifolia Steph. from India. J Bryol 11: 709-714. doi: 10.1179/jbr.1981.11.4.709

Udar, R., U.S. Awasthi, and F. Shaheen. 1982. A new Caudelejunea from India. Bryologist 85: 329-331. doi: $10.2307 / 3243056$

Udar, R. and A. Jain. 1984. Liverworts if Kerala I. Marchantiales. Indian J Forest 7: 300-305

Udar, R. and D. Kumar. 1976. Genus Cephalozia in Eastern Himalaya. Geophytology 6: 35-45.

Vaňa, J. and D.G. Long. 2009. Jungermanniaceae of the Sino-Himalayan region. Nova Hedwigia 89 (3-4): 485-517. doi: 10.1127/0029-5035/2009/0089-0485

Wang, J., M.J. Lai, and R.L. Zhu. 2011. Liverworts and hornworts of Taiwan: An updated checklist and floristic accounts. Ann Bot Fennici 48: 369-395. doi: 10.5735/085.048.0501

Wigginton, M.J. 2009. Checklist and distribution of the liverworts and hornworts of Sub-Saharan Africa, including the East African Islands. Trop Bryol Res Rep 8: 1-116.

Zhu, R. L. 2006. New checklist of Chinese liverworts, hornworts, and takakiophytes. 3rd version. (http://life.ecnu.edu.cn/sitez/zrl/images/CHECKLIST \%200F\%chinese\%20LIVERWORTS.pdf.)

Zhu, R. L. \& M.L. So. 2001. Epiphyllous liverworts of China. Nova Hedwigia 121: 1-418. 